\title{
SOIL QUALITY MONITORING FOR SUSTAINABLE AGRICULTURE
}

\author{
M.H. BEARE ${ }^{1}$, K.C. CAMERON ${ }^{2}$, P.H. WILLIAMS ${ }^{1}$ \\ and C. DOSCHER ${ }^{3}$
}

\author{
${ }^{I}$ Crop \& Food Research, Ltd., Canterbury Agriculture \& Science Centre, Lincoln \\ ${ }^{2}$ Lincoln Soil Quality Research Centre, Lincoln University \\ ${ }^{3}$ Department of Natural Resources Engineering, Lincoln University
}

\begin{abstract}
Most farmers are highly conscious of the importance of sustainable land management. However, the economics of present day agriculture place ever increasing pressure on farmers to intensify land-use, often exceeding the margins of what is truly sustainable. As a result, farmers increasingly demand more information and better tools for monitoring the sustainability of their agricultural management. This paper describes work in progress. It is our intent to present an overview of our research and development of a Soil Quality Monitoring System (SQMS). The SQMS is designed as an on-farm tool for monitoring and interpreting changes in soil quality that reflect on the sustainability of agricultural management practices. The paper focuses on the philosophical and theoretical basis of our research, the specific approach we have taken and some future prospects for the SQMS.
\end{abstract}

Keywords: Soil quality, sustainability, indicators, on-farm monitoring, agriculture productivity

THE SOIL RESOURCE

Life on earth depends critically on the soil resource. Soil is not only an important medium for plant growth but also a treatment filter for maintaining water quality, a key component in the regulation of the global biogeochemical cycles and an important medium for the disposal and degradation of wastes. Despite the importance of these functions, we often treat soil with contempt, often referring to it as 'dirt' and describing things as 'soiled' when no longer saleable.

Nevertheless, history teaches us of the need to protect the quality of our soil. For example, Ancient Mesopotamia grew and flourished due to the successful irrigation of soils. The capacity to increase crop yields enabled the inhabitants of the region to develop an urban society and amongst other things to invent writing. However, problems of soil salinity and silting up of irrigation channels caused the agricultural systems to fail until the civilisation declined and eventually became extinct (Hillel 1992). Similarly, soils in the Mediterranean region once supported the successful ancient civilisations of the Phoenicians, Greeks and Romans. In this case deforestation, over-grazing, and overcultivation of their soils caused extensive erosion leaving the barren hillsides which remain in many parts of the region today.

We ignore these lessons of the past at our peril. The same problems of soil degradation threaten many parts of the world today. It is estimated that the soil in $11 \%$ of the vegetated area of the world, an area the size of China and India combined, has been degraded since 1945 (Hammond 1992). Furthermore, recent estimates indicate that the earth is losing 24 billion tonnes of topsoil a year (Bakker 1990). This is equivalent to about 9.6 million hectares or about one third of the total area of New Zealand being lost each year. The rate of soil development is nowhere near as fast, with estimates of less than $0.1 \mathrm{~mm}$ depth per year being produced by natural weathering of parent material (Lal 1984). 


\section{Importance of New Zealand's soil}

Land based industries are still the main generator of New Zealand's export income. In 1994 our agriculture export income was $\$ 11.5$ billion, which represents $60 \%$ of NZ's total export income (Statistics NZ 1995). With implementation of the GATT agreement, agriculture earnings are projected to increase between $42 \%$ - $94 \%$ by the year 2001 (MAF 1994). Although nearly $61 \%$ of New Zealand's land area is used for agricultural production in one form or another (arable cropping, dairy, horticulture,etc), only $12 \%$ of it is suitable for cultivation and much of this land is also under threat from erosion, degradation and urban expansion (Statistics NZ 1995). The damage caused to the East Cape by Cyclone Bola in 1988 is testimony to the fragile nature of some of our soils.

\section{THE SOIL RESOURCE AND SUSTAINABLE AGRICULTURE}

Our international obligations under the Agenda 21 agreement of the United Nations Conference on Environment and Development in 1992 require us to promote sustainable development and conservation enhancement. Similarly, the Resource Management Act of 1991 has as its overarching tenet the sustainable management of natural and physical resources. The requirements of the Agenda 21 agreement and the RMA can only be met if we have a thorough understanding of the fundamental processes at work in different land use systems and if environmental impacts are assessed over a sufficiently long time frame.

Under GATT there will be increased opportunities for primary production exports providing these are produced in a sustainable and environmentally friendly manner. The International Organisation for Standardisation, based in Geneva, has developed an international standard for environmental management (ISO 14000). Due to a growing global awareness of environmental issues, such as maintaining environmental health for future generations and the sustainable use of natural resources, this new standard will undoubtedly influence world trade (Spencer 1995).

Evidence that New Zealand farmers and farming practices are sustainable will be essential to meet ISO 14000 standards of production. Under GATT our export products will meet the increased scrutiny of countries wishing to exclude us on the basis of nontariff trade barriers, such as claims of unsustainable farming systems (MAF 1994). Our current promotion of products that are produced in a 'clean green' manner will need to be sufficiently justified to satisfy the environmental consciousness of overseas and local buyers. Sustainability indicators, such as those that describe the health of the soil resource, will be essential to provide evidence that our farming practices meet ISO 14000 standards of production.

The vast majority of farmers are highly conscious of the importance of sustainable land-use, as their immediate livelihood depends directly upon it. Their concerns are echoed by a growing public awareness of the impacts of agriculture on the wider environment. However, the economics of present day agriculture place ever increasing pressure on farmers to intensify land-use, often exceeding the margins of what is truly sustainable. As a result, farmers increasingly demand more information and better tools for monitoring the sustainability of their agricultural management.

For these reasons, our research emphasises a "bottom-up" approach to sustainable management, placing the land manager at the centre of measurement and monitoring programmes. In our view, an approach that stresses the needs and direct involvement of land managers holds much greater potential for wide scale adoption of sustainability monitoring and management programmes than a "top down" regulatory approach.

\section{What is soil quality?}

We all recognise the need for clean water and clean air to maintain a healthy environment, yet few people recognise that our wellbeing also depends upon high quality soil. Soil quality, or soil health, can be defined in simplest terms as "the fitness of soil for use". In agricultural systems, high quality soil provides for the sustained and productive growth of crops with minimal impacts on the wider environment. In general, high quality agricultural soils have high nutrient availability and aeration, good infiltration and retention of water, are structurally stable, and promote a high level of biological activity.

It is generally accepted that intensive agricultural production leads to a decline in soil 
quality. While degradation of soil quality can take place rapidly, restoration of degraded soil tends to be a slow and costly process. For this reason, it is essential that farmers and growers monitor soil quality to avoid soil degradation, and in so doing, preserve the production capabilities of the land and protect the wider environment.

\section{SOIL QUALITY MONITORING FOR SUSTAINABLE AGRICULTURAL MANAGEMENT}

A Soil Quality Monitoring System (SQMS) is being developed to provide farmers, farm consultants and field scientists with a system for monitoring and interpreting changes in soil quality that reflect on the sustainability of agricultural management practices. In keeping with our philosophy of a "bottom-up" approach to sustainable management, the SQMS is designed specifically for on-farm use. It not only provides a system for describing the health of soil but also functions as a tool for predicting the impact of existing management practices on the sustained productivity of individual paddocks.

The SQMS is not intended as a one-off measure of soil health. Although a one-off measure of soil quality can reveal much about the current condition of the soil resource, it may have little value in predicting the impact of recent management on current and future agricultural productivity. This is because losses or gains in soil quality often lag behind changes in agricultural management. For example, in the case of a long-term, intensively cultivated cropping soil recently converted to improved pasture management, the structural condition of the soil is likely to be relatively poor, largely due to the long history of intensive cultivation and low organic matter returns. However, where best management practices are employed, the prospects for improvements in soil structure under pasture are high. While a one-off measure of soil structure might be interpreted to imply that the management is unsustainable from a pasture production standpoint, routine annual monitoring would be expected to reveal improvements in soil structure that increase the prospects for future agricultural productivity.

Therefore, by describing both the current health of the soil and the trajectory of change in individual indicators, it will be possible to predict the impact of recent management practices on agricultural productivity. Furthermore, where there is evidence of declining soil quality, information on the affected properties will be valuable in determining the cause of the decline and in identifying suitable management alternatives (ie. remedies). The following sections describe the four primary phases involved in research and development of the SQMS.

\section{Identifying suitable on-farm indicators}

The first step in this phase of the research involved identifying indicators of soil quality that are suitable for NZ agricultural conditions. The following criteria were adapted from recommendations of the workshop on Soil Quality Indicators in New Zealand held at Lincoln University (Cameron et al. 1996). Indicators should be:

1. Scientifically valid;

2. Relatively accurate and precise;

3. Sensitive to changes in soil management; and

4. Related to plant and animal productivity and health in a predictable way.

For indicators to be suitable for on-farm monitoring of soil quality some additional criteria apply. On-farm indicators must be:

1. Easy and practical to use by farmers, farm consultants, and scientists alike;

2. Relatively cost-effective to measure;

3. Subject to straightforward interpretation.

Although many potential indicators of soil quality meet the primary criteria, relatively few meet the more stringent "on-farm" criteria. The indicators selected for possible inclusion in the SQMS are given in Table 1. Evaluations of the proposed on-farm indicator methods were carried out on paddocks representing three contrasting management histories (sheep pasture, dairy pasture, and arable cropping). The precision of each method was determined from replicated measurements on individual paddocks and their accuracy was evaluated by comparing them to established research methods. The sensitivity of the on-farm methods to changes in soil management was evaluated using 
historical data sets (e.g. Winchmore long-termPTrial, Restorative Crops Trial, Canterbury Earthworm Survey) or by tests on existing research trials (e.g. Selwyn Stewardship Monitoring Farms, Lincoln University Mixed Cropping Farm). The conclusions drawn from these evaluations are given in Table 1. As the Soil Fertility Service (AgResearch) Quick Test is an established method, further evaluations of the nutrient availability and $\mathrm{pH}$ indicators were not undertaken.

TABLE 1: Evaluating the suitability of on-farm methods for soil quality monitoring.

\begin{tabular}{|c|c|c|c|c|}
\hline $\begin{array}{l}\text { Soil Quality } \\
\text { Indicator }\end{array}$ & $\begin{array}{l}\text { On-farm } \\
\text { Method }\end{array}$ & $\begin{array}{l}\text { Research } \\
\text { Method }\end{array}$ & Suitability & Accept \\
\hline $\begin{array}{l}\text { Water Holding } \\
\text { Capacity }\end{array}$ & $\begin{array}{l}\text { Water content of } \\
\text { saturated/drained } \\
\text { core }(75 \mathrm{~mm})^{1}\end{array}$ & Tension Tables & $\begin{array}{l}\text { High precision, } \\
\text { High accuracy, } \\
\text { Low sensitivity }\end{array}$ & \\
\hline Bulk Density & $\begin{array}{l}\text { From dry wt. of a } \\
75 \mathrm{~mm} \text { core }^{1}\end{array}$ & Gamma Probe & $\begin{array}{l}\text { High precision, } \\
\text { High accuracy, } \\
\text { Moderate to low } \\
\text { sensitivity }\end{array}$ & $\check{s}$ \\
\hline $\begin{array}{l}\text { Water Infiltration } \\
\text { Rate }\end{array}$ & $\begin{array}{l}\text { Single ring } \\
\text { infiltrometer }^{1}\end{array}$ & $\begin{array}{l}\text { Double ring } \\
\text { Infiltrometer }\end{array}$ & $\begin{array}{l}\text { Low precision, } \\
\text { Low accuracy, } \\
\text { Not practical for } \\
\text { on-farm use. }\end{array}$ & \\
\hline SoilCompaction & $\begin{array}{l}\text { Hand held } \\
\text { penetrometer }\end{array}$ & $\begin{array}{l}\text { Conventional } \\
\text { Penetrometer }\end{array}$ & $\begin{array}{l}\text { High precision, } \\
\text { High accuracy } \\
\text { Sensitivity being } \\
\text { evaluated }\end{array}$ & $\breve{s}^{2}$ \\
\hline $\begin{array}{l}\text { Soil Structural } \\
\text { Stability }\end{array}$ & $\begin{array}{l}\text { Aggregate } \\
\text { Stability Method }\end{array}$ & $\begin{array}{l}\text { Aggregate } \\
\text { Stability }\end{array}$ & $\begin{array}{l}\text { High precision, } \\
\text { High accuracy } \\
\text { Sensitivity being } \\
\text { evaluated }\end{array}$ & $\breve{s}^{2}$ \\
\hline $\begin{array}{l}\text { Visual } \\
\text { Assessment }\end{array}$ & $\begin{array}{l}\text { after McLaren \& } \\
\text { Cameron (1996) }\end{array}$ & None & $\begin{array}{l}\text { High precision, } \\
\text { Good Sensitivity }\end{array}$ & $\check{s}$ \\
\hline Earthworms & $\begin{array}{l}\text { Quadrat sample/ } \\
\text { hand sorting }\end{array}$ & None & $\begin{array}{l}\text { Moderate precision, } \\
\text { Good Sensitivity }\end{array}$ & , $\check{\mathrm{s}}$ \\
\hline $\begin{array}{l}\text { Nutrient } \\
\text { availability } \\
(\mathrm{P}, \mathrm{K}, \mathrm{S}, \mathrm{Mg})\end{array}$ & $\begin{array}{l}\text { Quick Test } \\
\text { (AgResearch- } \\
\text { Soil Fertility } \\
\text { Service [SFS]) }\end{array}$ & None & Approved method & $\check{\mathrm{s}}$ \\
\hline $\mathrm{pH}$ & $\begin{array}{l}\text { Quick Test } \\
\text { (SFS) }\end{array}$ & None & Approved method & $\check{\mathrm{s}}$ \\
\hline
\end{tabular}

${ }^{1}$ method was adapted from the USDA Soil Quality test kit.

${ }^{2}$ method accepted based on preliminary findings of a sensitivity evaluation.

\section{Developing the Soil Quality Monitoring System}

In this phase of the research, the indicator methods found to be suitable for on-farm 
use were compiled to form an integrated monitoring system. The SQMS includes: 1) guidelines for implementing a soil quality monitoring programme; 2) information on the inherent properties of soils that are needed to properly interpret the indicator results; 3 ) descriptions of the indicator methods; 4) guidelines for interpreting their results; and 5) recommendations for reversing trends of soil quality decline where they occur. As a logical extension of the SQMS, Crop \& Food Research and Lincoln Soil Quality Research Centre are currently developing a test kit which contains the essential materials needed for routine use of the SQMS.

Of the nine indicators described in Table 1, two were rejected as unsuitable for inclusion in the SQMS. While water-holding capacity was rejected as a monitoring indicator because of its insensitivity to changes in management, the on-farm method is recommended for measurement as an inherent soil property. In addition to low precision and accuracy, the method for measuring water infiltration rate was found to be impractical for on-farm use.

Apart from the visual assessment method, each of the SQMS indicators is indexed quantitatively. The visual assessment method includes a qualitative description of the soil profile that is useful in interpreting results of the other indicators. Once collected, the indicator results are plotted in a data log where changes in their values can be monitored annually (e.g. Fig. 1A and B). The data logs include optimum ranges for measures of chemical fertility (nutrient availability and $\mathrm{pH}$ ) and target threshold levels for all other indicators. Suitable adjustments in these values are given where differences in soil type or land-use are important. The example given in Fig 1 A depicts a decline in Olsen-P levels under pasture (years 1-5) which is corrected by an addition of superphosphate in the 6th year of monitoring. The decline and restoration of soil structural condition in a typical mixed cropping rotation (pasture to arable cropping to pasture) are shown in Fig 1B.

\section{User group acceptability}

An essential ingredient in the success of any monitoring system is its acceptability to the target user groups. This phase of the research seeks to gain feedback from farmers, farm consultants and scientists that can be used to refine the monitoring system. To this end, demonstrations of the SQMS and test kit are being demonstrated to selected groups of potential users for direct feedback. Hands-on evaluations of the SQMS and test kit are also planned.

\section{Monitoring system performance}

The ultimate test of the SQMS rests in its ability to predict changes in agricultural sustainability. The performance assessment phase of our research focuses on describing quantitative relationships between SQMS indicator values and measures of sustainability. Agricultural sustainability is most often equated to qualities of productivity, profitability, resilience, social acceptability and environmental friendliness (Gomezet al. 1996). The condition or health of the soil resource influences in one form or another each of these qualities of sustainability. However, some measures of agricultural sustainability (e.g. profitability and social acceptability) depend on factors that extend well beyond those of soil quality. Profitability, for example, is reduced by high labour costs, excessive or underuse of fertilisers and pesticides, loss of product marketability and reductions in commodity prices. Our research has focused on agricultural productivity as the most appropriate measure of sustainability for evaluating the performance of the SQMS because it is directly affected by the quality of the soil resource and can quite reasonably be influenced by changes in agricultural management.

One of the major challenges to quantifying agricultural productivity involves normalising the measurements to account for differences in land-use (e.g. arable cropping, dairy pasture, etc.), crop type (e.g. wheat, maize, asparagus) and environmental constraints (e.g. soil type, climate etc). This is particularly important in a monitoring programme where the objective is to compare year-to-year changes in paddock productivity under different crops. Our solution to this challenge is to index measures of paddock productivity against the regional (or local) average annual productivity of a specific crop (eg. pasture cover, wheat yield). Productivity threshold (PT) levels are set as a fixed percentage of the productivity index (PI) to denote boundaries between sustainable and unsustainable practices. Using this approach, the threshold levels for a sustainable practice can be tailored to the specific expectations of 


\section{(A) SOIL PHOSPHORUS DATA LOG}

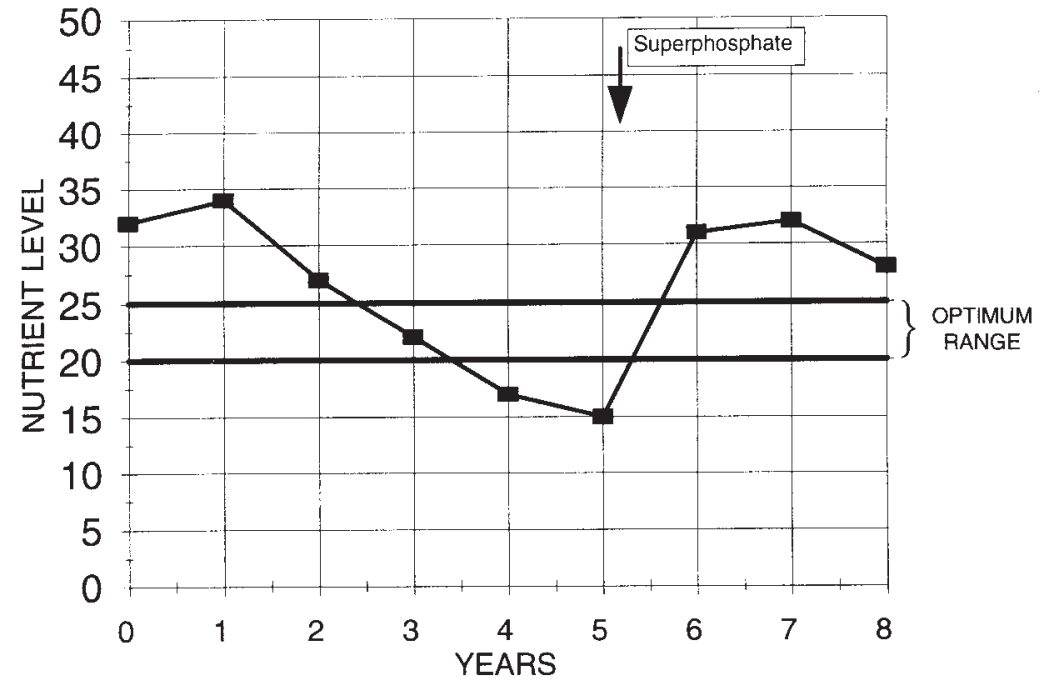

\section{(B) STRUCTURAL CONDITION DATA LOG}

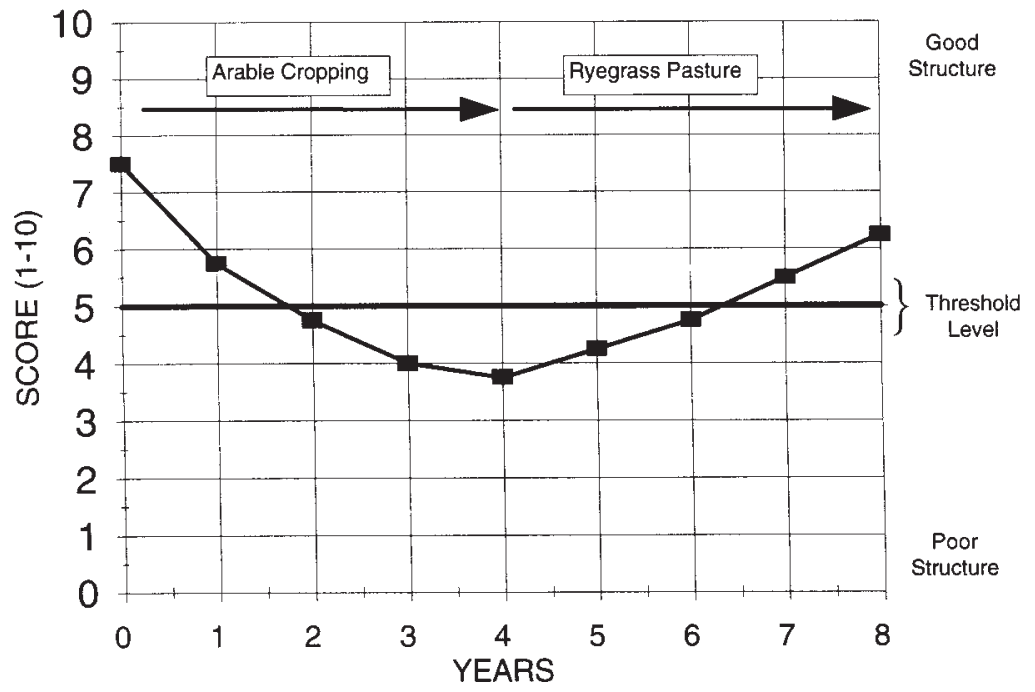

FIGURE 1: Examples of the soil phosphorus (A) and soil structural condition (B) data logs used in the Soil Quality Monitoring System. The phosphorus data log depicts Olsen-P levels in a long-term pasture soil before and after superphosphate fertiliser applications. The structural condition data $\log$ shows the decline and restoration of soil structural condition in a typical mixed-cropping rotation. 
farmers, farm consultants and regional governing bodies. Depending on regional or local circumstances, PT values may be judged to be greater than, less than or equal to one (i.e. where $\mathrm{PT}=100 \%$ of the regional average annual productivity). Examples of productivity indices for 13 performance assessment paddocks located on the Lincoln University and Crop \& Food Research farms are given in Table 2.

TABLE 2: Examples of yield and productivity data from selected paddocks on the Lincoln University and Crop \& Food Research, Ltd farms.

\begin{tabular}{lccc}
\hline $\begin{array}{l}\text { Paddock } \\
\text { Management }\end{array}$ & Yield(t/ha) & Yield (t/ha $)^{1}$ & Productivity \\
Regional Av. & Index \\
\hline
\end{tabular}

$\begin{array}{llll}\text { Mixed Cropping } & & & \\ 1 \quad \text { Wheat } & 9.2 & 8.0 & 1.15 \\ 2 \text { Wheat } & 8.5 & 8.0 & 1.06 \\ 3 \text { Wheat } & 6.1 & 8.0 & 0.76 \\ 4 \text { Wheat } & 5.8 & 8.0 & 0.73 \\ 5 \text { Barley } & 6.1 & 6.2 & 0.98 \\ 6 \text { Barley } & 5.1 & 6.2 & 0.82 \\ 7 \text { Barley } & 3.3 & 6.2 & 0.53 \\ 8 \text { Vining Pea } & 6.5 & 5.9 & 1.10 \\ 9 \text { Ryegrass } & 1.25 & 1.20 & 1.04 \\ \text { Dairy Pasture } & & & 1.33 \\ 10 \text { Pasture } & 16.0 & 12.0 & 1.00 \\ 11 \text { Pasture } & 12.0 & 12.0 & 1.10 \\ 12 \text { Pasture } & 13.2 & 12.0 & 0.85 \\ 13 \text { Pasture } & 10.3 & 12.0 & \end{array}$

${ }^{1}$ Unless otherwise stated, average yield data were taken from the 1996 Crop profiles (A. Dunbier and H.J. Bezar, unpubl.). Average wheat yields were estimated from data on high yielding biscuit wheats.

Two different approaches have been used to evaluate the SQMS performance. The first approach seeks to establish relationships between measures of current year productivity (eg. crop yields, pasture production, milk solids) and one-off measures of soil quality using SQMS values from paddocks representing different agricultural land-uses (eg. sheep pastures, dairy pastures and arable cropping). An example of this approach is given in Fig. 2. In this case our preliminary results indicate that PI is positively related to structural condition scores on the 13 performance assessment paddocks shown in Table 2. Describing relationships between PI and the SQMS indicators over a broad range of soil types and management histories may help to reveal those with particular sensitivity under specific agricultural conditions. Where these relationships are well known, PT levels may be used to identify critical indicator values (Fig. 2). Using the example given, paddocks with structural condition scores of less than about 4.8 would not be expected to meet the productivity threshold for a sustainable practice.

A second, and probably more rigorous, assessment of the SQMS will come from its use in monitoring programmes. Though still in the planning stages, this approach will involve trialling the SQMS over a period of several years on farms representing a wide range of soil types, climatic regimes and management histories. Wherever possible, we will involve existing monitoring programmes in each of the major agricultural districts and sectors of New Zealand. Our objective is to confirm that results of the SQMS can be used to predict, with some confidence, losses or gains in agricultural productivity.

\section{FUTURE PROSPECTS}

As discussed previously, development and refinement of the SQMS is on-going. Though preliminary results are promising, our assessment of the performance of the SQMS in terms of sustainable production is incomplete. Further, hands-on evaluation of the SQMS and test kit by farmers, farm consultants and other potential end-users is also 


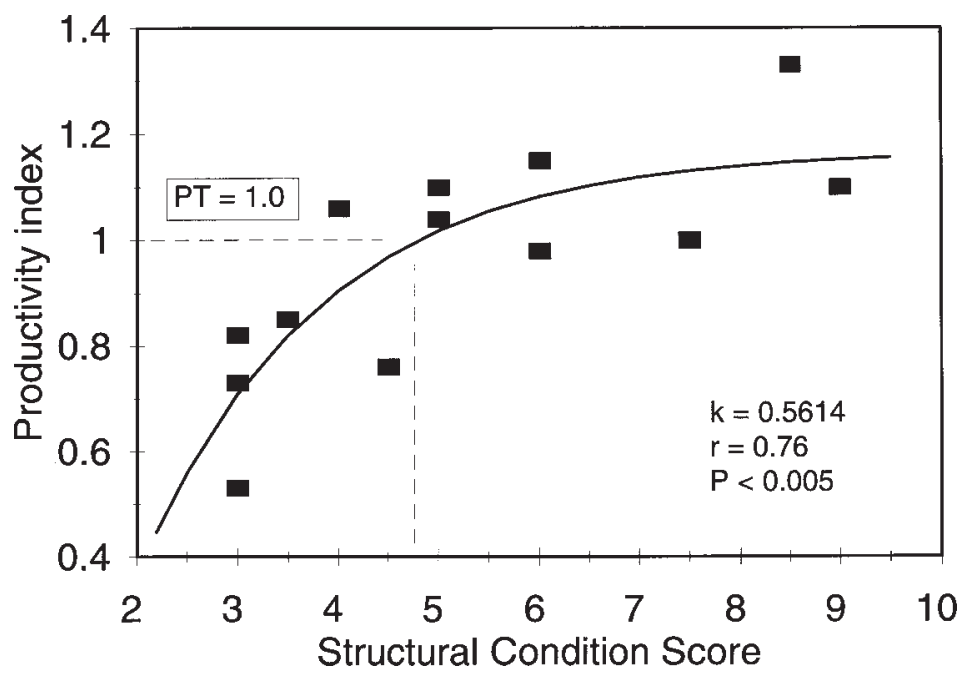

FIGURE 2: Preliminary findings from the performance assessment of the Soil Quality Monitoring System showing a positive relationship between the soil structural condition score and the Productivity Index on 13 paddocks under arable, mixed-cropping and dairy pasture management. Structural condition $=\mathbf{4 . 8}$ where the productivity threshold $(\mathbf{P T})=\mathbf{1 . 0}$.

needed. Ultimately, the most rigorous test of the SQMS will come from on-farm trials carried out over a period of several years in a regular monitoring programme. Once the utility of the SQMS is firmly established, there is the opportunity to network individual and local monitoring programmes to develop regional and national databases that may be used to evaluate trends in resource management and predict sustainable agricultural productivity.

The SQMS may be extended into other areas of sustainability monitoring as well. One area of particular concern involves the impact of agricultural management on the wider environment. For example, recent attention has turned to the role of agriculture in nitrate contamination of surface and ground waters. Although simple nitrate tests are available commercially, to our knowledge practical use of these methods on an on-farm basis has not been established.

Finally, the SQMS may eventually be linked with other on-farm management tools such as those used for making fertiliser recommendations and pest and disease forecasting. This approach would provide land managers with a set of quantitative tools to make more informed decisions on best management practices. In the end, agricultural sustainability will always be vulnerable to the vagaries of the weather, market fluctuations, and national and international monetary policies. However, the development of a robust soil quality monitoring system provides a tool to assist land-users in monitoring and managing the effects of agricultural production on the soil resource, thereby, markedly improving their chances of achieving a truly sustainable system of agriculture.

\section{ACKNOWLEDGEMENTS}

The authors wish to acknowledge the financial support of MAF Policy and the valuable input of our soil quality research team (Ian Cornforth, Ron McLaren, Heather Russell, Neil Smith, Craig Tregurtha, and Paula Wilson). 
Perspective. Canadian Scholars Press, Toronto. 530p.

Cameron, K.C. Cornforth, I.S., McLaren, R.G., Beare, M.H., Basher, L.R., Metherell, A.K., and Kerr, L.E. 1996. Soil Quality Indicators for Sustainable Agriculture in New Zealand: Proceedings of a Workshop. Lincoln Soil Quality Research Centre, Lincoln University, New Zealand.

Gomez, A.A., Swete Kelly, D.E., Syer, K.K., and Coughlan, K.J., 1996. Measuring sustainability of agricultural systems at the farm level. Pp 401-409.In: Methods for Assessing Soil Quality, J.W. Doran and A.J. Jones (Eds); Special publication no. 49, Soil Science Society of America, Madison, USA.

Hammond, A.L. (ed) 1992. World Resources 1992-3. Oxford University Press, Oxford. Hillel, D., 1992. Out of the Earth: Civilisation and the Life of the Soil. The Free press, New York. 321p.

MAF, 1994. GATT, A Big Deal for NZ Agriculture. MAF, Wellington. 152p.

McLaren, R.G. and Cameron, K.C., 1996. Soil Science: Sustainable Production and Environmental Protection. Oxford University Press, Auckland.

MoRST, 1992. Review of Forage Research. Science Review No. 8. MoRST, Wellington. $66 \mathrm{p}$.

Spencer, B., 1995. Potential impact of ISO14000 on Australasian Agriculture. Agricultural Science, August 1995.

Statistics NZ, 1995. Facts New Zealand. Statistics New Zealand, Wellington. 221p. 